DOI 10.37882/2223-2982.2021.07.40

\title{
ЭКСПЕРИМЕНТАЛЬНОЕ ОБОСНОВАНИЕ ТЕХНОЛОГИЧЕСКОГО ФОРМИРОВАНИЯ ПРИКЛАДНОЙ ФИЗИЧЕСКОЙ КУЛЬТУРЫ СТУДЕНТОВ МОСТОСТРОИТЕЛЬНЫХ СПЕЦИАЛЬНОСТЕЙ
}

\section{EXPERIMENTAL JUSTIFICATION \\ OF TECHNOLOGICAL FORMATION \\ OF APPLIED PHYSICAL CULTURE OF STUDENTS OF BRIDGE-BUILDING SPECIALTIES}

L. Tsareva

S. Smolyar

V. Mulin

Summary: This article is devoted to the issues of ensuring vocational and applied physical fitness, which determines the psychophysical readiness of students for the future profession.

A characteristic feature of the process of modeling the professional physical culture of students at the stage of vocational education is its focus on the formation of the physical culture of the individual, which contributes to the successful development of the profession of a bridge builder and transport tunnels [1].

On the basis of a professional analysis of working conditions, an experimental program was developed for the construction of bridges and transport tunnels, providing a complex with a focused impact on the personality of the professional. It is based on the current programs of physical nutrition and reflects the main content of the course of physical education of university students $[7,11]$.

Keywords: professional analysis, applied physical culture, vocational education, physical education program, psychophysical qualities, vocational training, motor abilities.

\author{
Царева Любовь Васильевна \\ К.n.н., дочент, Дальневосточный государственный \\ университет путей сообщения, г. Хабаровск \\ Lyubov.tsareva.60@mail.ru \\ Смоляр Сергей Николаевич
}

К.n.н., дочент, Дальневосточный государственный университет путей сообщения, г. Хабаровск

smolyar@list.ru

Мулин Владимир Васильевич

Профессор, Дальневосточный государственный университет путей сообщения, г. Хабаровск

Mulin58@yandex.ru

Аннотация: Данная статья посвящена вопросам обеспечения профессионально-прикладной физической подготовленности, определяющей психофизическую готовность студента к будущей профессии.

Характерной особенностью процесса моделирования профессиональной физической культуры студентов на этапе профессионального образования является его направленность на формирование физической культуры личности, способствующей успешному освоению профессии инженера-строителя мостов и транспортных тоннелей [1].

Полученные результаты могут быть направлены на повышение эффективности целостного процесса профессионального образования студентов, обеспечивающего становление личности специалиста и его прикладной физической культуры.

На основе профессиографического анализа условий труда специалистов по строительству мостов и транспортных тоннелей была разработана экспериментальная программа, обеспечивающая комплексное и целенаправленное воздействие на личность профессионала. Она составлена на основе ныне действующих программ физического воспитания и отражает основное содержание курса физической культуры студентов вуза [7, 11].

Ключевые слова: профессиографический анализ, прикладная физическая культура, профессиональное образование, программа по физическому воспитанию, психофизические качества, профессионально-прикладная подготовленность, двигательные способности.

специфичность их труда и повышенные требования к специальной подготовленности личности профессионала определяет потребность разработки и обоснования комплекса конкретных мер педагогического воздействия с целью повышения профессионального мастерства и формирования профессиональной физической культуры личности. [8, 9, 10].

\section{Материалы и методы исследования}

С целью обоснования технологического формирования профессиональной физической культуры у 
студентов нами были изучены особенности трудовой деятельности мостостроителей, а также требования, предъявляемые производством к их физическим, психофизиологическим и личностным качествам.

Для решения данной цели был организован педагогический эксперимент, в котором приняли участие работники Дальмостостроя (84 чел.), средний возраст 38 лет, имеющие высшее профессиональное образование и стаж работы по специальности 10-15 лет.

Для получения сведений о характере и условиях трудовой деятельности, интереса к профессиональной физической культуре (ПФК), об особенностях реализации физического воспитания с профессиональной направленностью проведено анкетирование.

Исследования показали, что процесс строительства железнодорожных мостов включает большой комплекс работ, особенностью которых является необходимость круглогодичного пребывания работающих на открытом воздухе при различной погоде. Работы под открытым небом ведутся при разработке котлованов под опоры, при закладке устоев, на перегрузке бетона и подаче его в тело опоры, на открытых участках временных бетонных заводов, сборке конструкций на земле, при монтаже на высоте и др. [2,6].

При сооружении мостов практически все виды строительно-монтажных работ выполняются в условиях повышенной опасности: на значительной высоте (25-40 м), над водой, высокой волне, в ограниченном пространстве, на ригелях опор, подмостях, в котлованах опор, в шпунтовых ограждениях, в зонах действия железнодорожных путей, вблизи высоковольтных линий электропередач и др.

По данным специалистов энерготраты у монтажников на строительстве железнодорожных мостов составляют 258 ккал/ч, что соответствует тяжелому физическому труду.

Изучение безопасности труда мостостроителей показало, что 66,4 \% несчастных случаев зарегистрировано на основных видах работ (монтажных, погрузочно-разгрузочных, бетонных, арматурных, электросварочных и др.), в то время, как на вспомогательных и подсобных (технологических переходах, подъемах и спусках по лестницам на опоры и в котлованы, ремонтных и др.) происходит 33,6 \% случаев. Изучение травмоопасности по видам работ позволило установить, что наибольшая доля - 11,6 \% случаев приходится на монтажные работы, которым свойственно многообразие выполняемых операций и технологическая сложность $[4,5]$.

В пределах года больше всего несчастных случаев от- мечается в июле, что возможно связано с неритмичностью и спецификой к концу полугодия. Однако в целом за холодное время года случаев травматизма происходит больше, что подтверждает влияние неблагоприятных метеорологических факторов при работе на открытом воздухе. Наибольшее увеличение случаев (на 1,6 \%) наблюдается к концу рабочей недели.

Изучение обстоятельств несчастных случаев позволило установить, что существенное влияние на травматизм оказывает производственный стаж исполнителей и опыт их работы в мостостроении. Риск травмирования у работающих со стажем до 1 года превышает средние показатели по данной профессиональной группе примерно в 5 раз. Вот почему так важно для молодых специалистов выполнение разработанных мероприятий по обеспечению безопасности мостостроительных работ еще на этапе обучения в вузе.

Установлено, что наиболее опасными видами деятельности мостостроителей являются: установка высокопрочных болтов, погружение в воду и наращивание секций свай-оболочек, установка балок на опорные части и др. Поэтому в инструкции по технике безопасности в качестве основного требования к специалисту по строительству железнодорожных мостов и тоннелей указывается на необходимость овладения навыками прикладного плавания. Это подтверждается и результатами проведенного нами анкетирования. Так, на вопрос: необходима ли специалисту данной профессии владеть навыками прикладного плавания - 67 \% опрошенных отметили, что обязательно.

Именно специфические условия сооружения мостов являются ведущим (из 112 опасных и вредных) фактором, способствующим возникновению опасных ситуаций и случаев травматизма. Существенное влияние на число несчастных случаев оказывают метеорологические факторы (пониженные или повышенные температуры, ветер, обледенение, туман и др.). Нарушение микроклимата приводит к существенным сдвигам в деятельности функциональных систем, угнетению защитных сил организма, распространению вирусных и острых респираторных заболеваний. Они являются негативными факторами, определяющими развитие хронических заболеваний дыхательной системы, у работников мостостроительных профессий. Это подтверждается результатами исследования, в ходе которого $61 \%$ опрошенных специалистов Дальмостостроя отметили простудные заболевания в числе основных профессиональных заболеваний (рис.1).

На второе место среди причин, способствующих возникновению опасных ситуаций, инженерно-технические работники поставили недостаточный уровень развития психофизиологических качеств личности. Это свиде- 


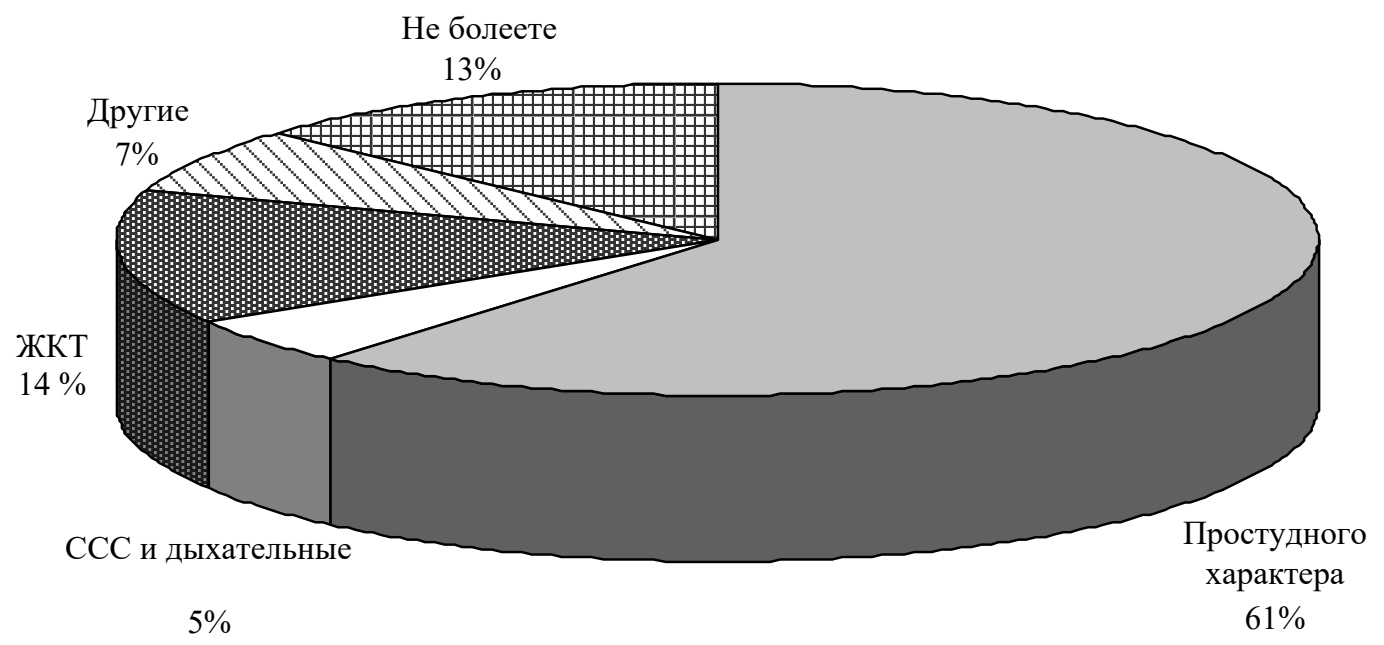

Рис. 1. Характерные заболевания работников мостостроительного производства

тельствует о необходимости на этапе профессионального образования больше уделять внимания формированию физического компонента профессиональной физической культуры личности мостостроителей.

Результаты проведенного анкетного опроса квалифицированных работников подтвердили также необходимость для выполнения профессиональных видов работ мостостроителей таких прикладных умений и навыков, как плавание (34\%), передвижение на ограниченной опоре (19\%), гребля на лодке (11\%), ориентирование на местности (8\%) и др. (19\%) (рис. 2).

Анализ полученных профессиографических данных определил, что труд инженера-строителя характеризуется чередованием периодов незначительной физической нагрузки и достаточно высокой (60 \%) двигательной активностью (3-10 км в день). Это требует развитие общей выносливости, способности длительное время сохранять высокую работоспособность. Данное качество зависит от правильного выбора рабочей позы. В анализируемом производстве возможно 3 вида рабочих поз: стоя (38 \%), сидя (14\%) и переменная - сидя-стоя, с наклоном головы и туловища вперед, руки согнуты в локтевом суставе (29 \%). В этой вынужденной позе работник находится 75-83 \% рабочего времени. Такая поза считается наиболее утомительной, для сохранения которой на $10 \%$ энергетических затрат больше, чем в положении сидя.

Результаты наблюдений показали, что основные трудовые процессы инженера-строителя обеспечиваются за счет малых и средних действий руками (24\%) и одновременно ногами (29\%) с сопровождением легких и точных движений кисти (33\%).

Санитарно-гигиенический раздел профессиограммы характеризуется действием таких факторов, как дис- комфортный климат: работа на открытом воздухе (57 \%), в условиях значительных перепадов температур, на сквозняке (33\%).

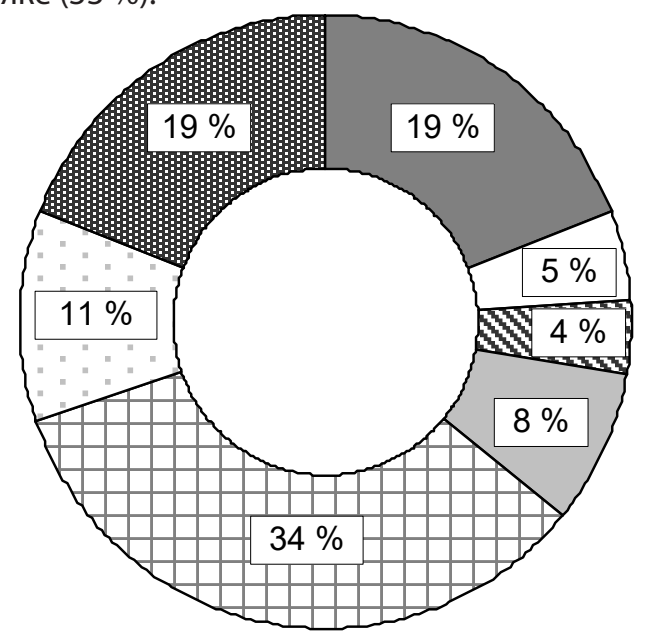

Рис. 2. Профессиональные умения и навыки, необходимые для выполнения специальных видов работ:

- передвижение на ограниченной опоре; $\square$ управление автотранспортом; $\square$ - езда на велосипеде; $\square$ - ориентирование на местности; 圈 - плавание; 目 - гребля на лодке; 目 - другие

К числу основных причин, мешающих работе, - $33 \%$ рабочих указали на шум, вибрацию, 59,7 \% - на запыленность и загазованность воздуха, 66,4 \% - на неудовлетворительные санитарно-гигиенические условия (плохое освещение, сквозняки и т.д.).

Источниками шума и вибрации являются буровые установки, механизмы для погружения свай и забивки шпунта, растворные узлы, а также ручной механизированный инструмент. Особенно высокие уровни шума на рабочих местах пескоструйщиков (до 123 ДБ). На площадках укрупнительного монтажа в радиусе 7,5 метров 
от пескоструйного аппарата уровни шума достигают 108 ДБ. Общая вибрация наиболее существенна на вибропогружателях, где величина виброскорости на органах управления превышает предельно-допустимые уровни в 2-4 раза. Значительная вибрация регистрируется также при использовании ручного механизированного инструмента (отбойные молотки, пневмотрамбовки, пмевногайковерты и др.).

Многие мостостроительные работы сопровождаются загрязнением воздуха рабочей зоны. При пескоструйных работах и в процессе приготовления бетонной смеси воздух загрязняется пылью с высоким содержанием двуокиси кремния. Концентрация этой пыли в воздухе рабочей зоны достигает 80 мг/м3, существенно превышая ПДК.

Рабочие места мостостроителей и рабочие площадки в вечернее и ночное время освещаются с помощью ламп накаливания преимущественно прямого светораспределения; за пределами зоны непосредственного освещения величины освещенности, как правило, очень низкие.

Таким образом, гигиеническая оценка условий труда мостостроителей позволяет судить о том, что на них действует ряд весьма значимых факторов, ведущими из которых являются: неблагоприятные метеорологические условия, существенное загрязнение воздуха рабочей зоны, высокие уровни шума и вибрации, недостаточная освещенность. К тому же необходимо учитывать

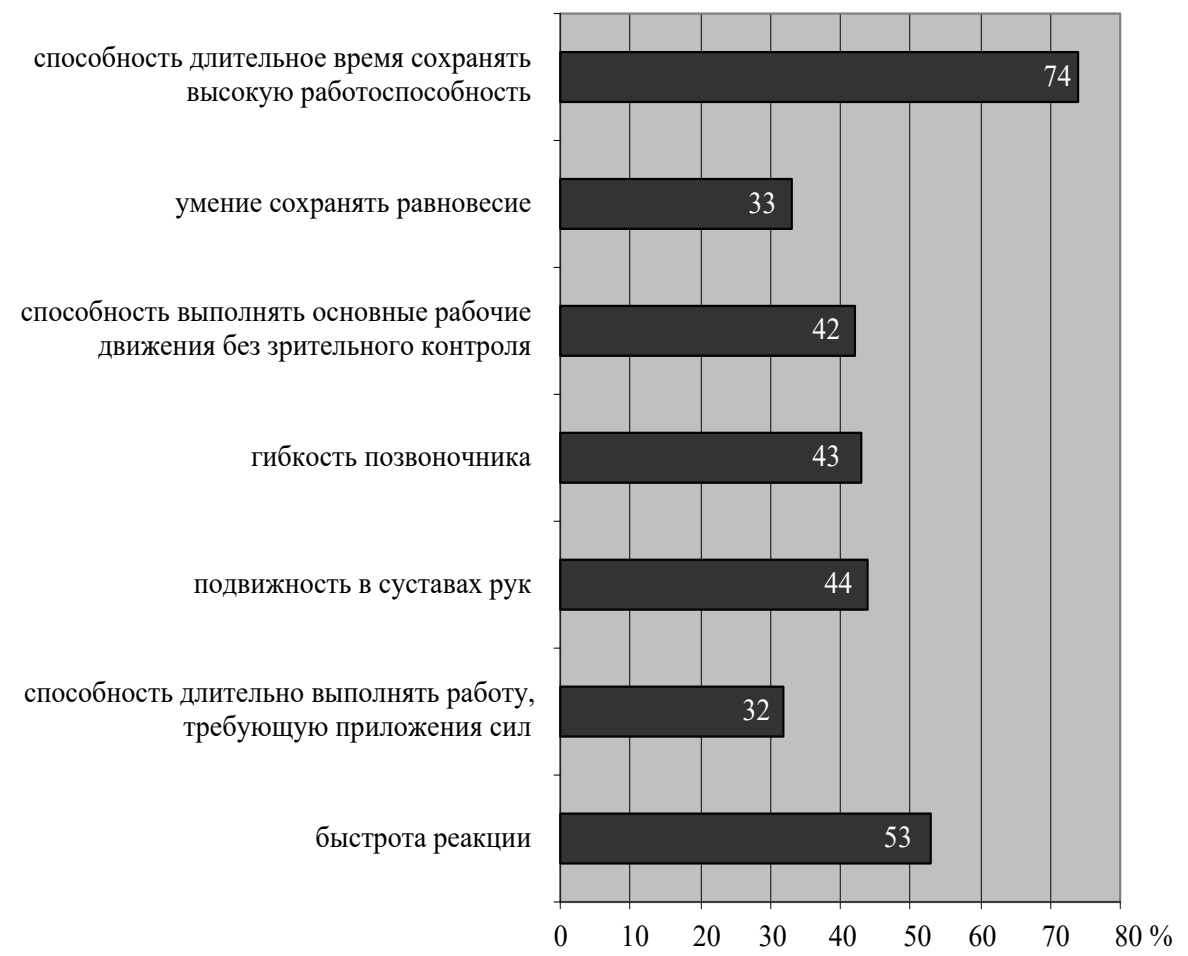

Рис. 3. Психофизические качества необходимые для специалистов-мостостроителей. возможность неблагоприятного воздействия профессионально-производственных факторов на организм мостостроителей отдельных профессиональных групп с учетом этапов строительства мостов.

Всестороннее изучение трудовой деятельности инженеров-строителей мостов и транспортных тоннелей позволило выявить комплекс физических и психофизиологических свойств и качеств, необходимых для представителей данной профессии (рис. 3,4$)$. К ним следует отнести такие качества, как общая выносливость, быстрота, функции внимания, умение сохранять равновесие, подвижность в суставах рук, гибкость позвоночника, эмоциональная устойчивость и личностные качества, составляющие структуру организаторских способностей инженера.

Подтверждением этого служат и результаты анкетирования специалистов данного профиля. Так, к числу наиболее важных профессиональных качеств, необходимых для успешной работы в производстве железнодорожных мостов и тоннелей, они отнесли общую выносливость - 74 \%, быстроту реакции - 53 \%, гибкость (подвижность в суставах рук - 44 \% и позвоночника - 43 \%), способность выполнять рабочие движения без зрительного контроля - $42 \%$, умение сохранять равновесие - 33 \%, силовую выносливость - 32 \% (рис. 3).

Анализ профессиональной деятельности инженерамостостроителя показал, что ему приходится действовать в постоянно меняющихся условиях производства. 
Это требует от него умений быстро приспосабливаться и перестраивать свою двигательную деятельность в соответствии с меняющейся обстановкой. Поэтому общая физическая, психическая выносливость и устойчивость к гиподинамии, быстрота и точность движений, развитие функций внимания являются одним из условий высокой квалификации современного инженера.

В деятельности специалиста по строительству мостов и транспортных тоннелей важную роль также играют качества: функции внимания - объем внимания (одновременно воспринимать несколько объектов); распределение внимания (выполнять несколько действий); переключение внимания (быстро переносить внимание с одного объекта на другой); концентрация внимания (умение сосредоточиться на одном объекте); устойчивость внимания (умение сосредоточиться длительное время на выполнение одного задания).

Это подтверждают и результаты анкетирования высококвалифицированных специалистов-мостостроителей (рис. 4).

Так, по мнению опрошенных в деятельности инженера большую роль играют переключение и распределение внимания - 57 \%; устойчивость внимания - $27 \%$; объем внимания - $15 \%$.

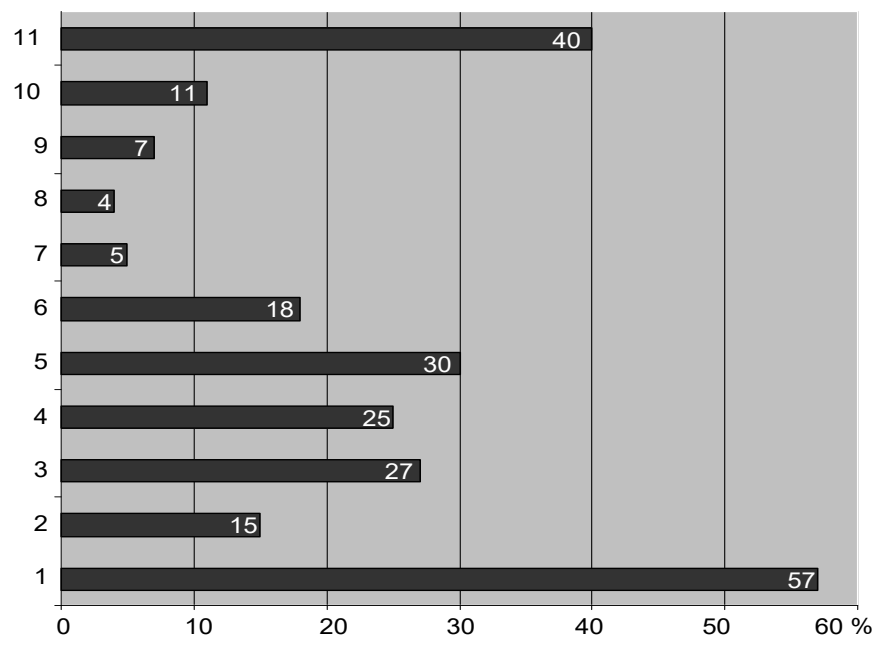

Рис. 4. Личностные, психические качества и функции мостостроителей: 1 - переключение и распределение внимания; 2 - объем внимания; 3 - устойчивость внимания; 4 - способность быстро принимать решение; 5 - эмоциональная устойчивость; 6 - инициативность; 7 - смелость; 8 - решительность; 9 - самообладание; 10 - стойкость; 11 - умение устанавливать контакты с коллегами

Труд инженера часто сопровождается значительным нервно-эмоциональным напряжением, обусловленным большой ответственностью за принятие решения, здоровье и жизнь подчиненных. В связи с этим, по данным анкетирования, важное значение для инженера имеет эмоциональная устойчивость - 30 \%; способность быстро принимать решения - $25 \%$.

Экстремальные условия требуют от специалистов и, прежде всего, от руководителей, также способность управлять своими чувствами, выдержки и самообладания. Эти волевые качества особенно необходимы в работе с людьми, они - одно из условий обеспечения нормального микроклимата в коллективе.

Профессиональная деятельность инженеров-мостостроителей предполагает наличие следующих личностных качеств, составляющих структуру организаторских способностей руководителя производства; умение устанавливать контакты с коллегами - $40 \%$; инициативность - $18 \%$; стойкость - $11 \%$; самообладание - $7 \%$; решительность $-4 \%$ (см. рис. 4).

Учитывая недостаточную изученность вопроса личностной подготовленности инженеров-мостостроителей, нами было проведено более глубокий и обстоятельный анализ отношений личности, необходимых для их эффективной профессиональной деятельности.

По разработанной и апробированной методике респондентам было предложено определить свои личностные качества при помощи девятибальной шкалы. В ходе исследования выявлены уровни сформированности целостной системы отношений личности и ее отдельных компонентов («к труду», «к делу», «к себе», «к людям и обществу», «к явлениям мира», «к физической культуре»).

Результаты анализа показали, что практически все изучаемые параметры оказались достаточно устойчивыми, но с некоторыми несущественными недостатками. Наиболее гармоничными являются отношения «к себе»скромность, разумность, самокритичность, надежность, гуманность, доброта и т.д. (средняя оценка - 4 балла «хорошо»); «к миру» - впечатлительность глубокомысленность, практичность, дальновидность и т.д. (3,8 балла); «к физической культуре» (3,8 балла) (рис. 5).

Самым значительным оказался разброс результатов в отношениях «к физической культуре» (рис. 6).

Следует отметить, что в настоящее время общепризнанно отношение к физической культуре, как важному фактору повышения экономической эффективности современного производства и социального развития трудовых коллективов. Поэтому респонденты оценивали свою физическую активность, понимание роли физических упражнений и т.п. Однако данному компоненту 5,9 \% опрошенных отметили у себя присутствие негативных отношений, часто вызывающих нарекания окружающих и требующих изменений (2 балла); 17,7\% респондентов 


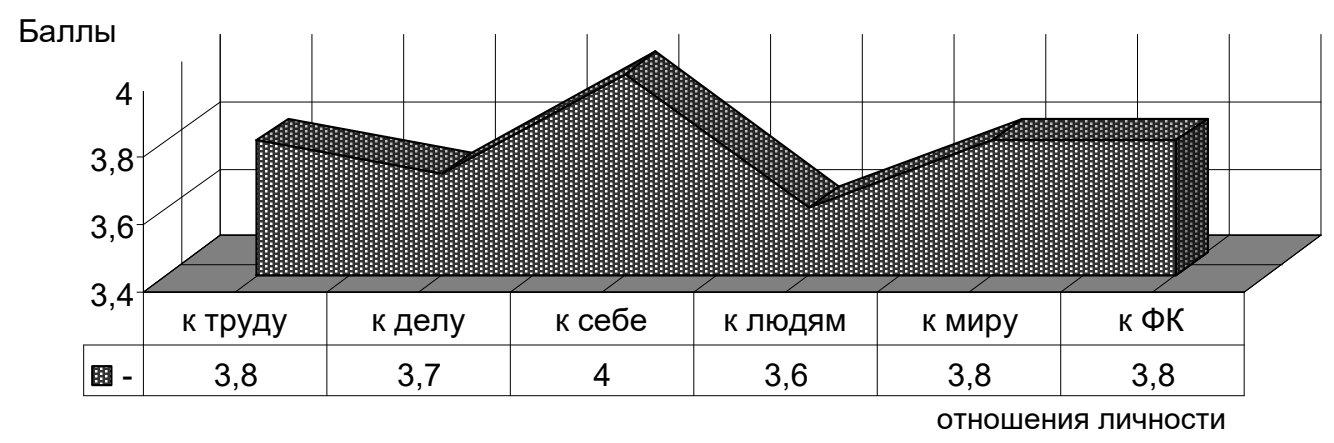

Рис. 5. Показатели средних значений сформированности отношений личности

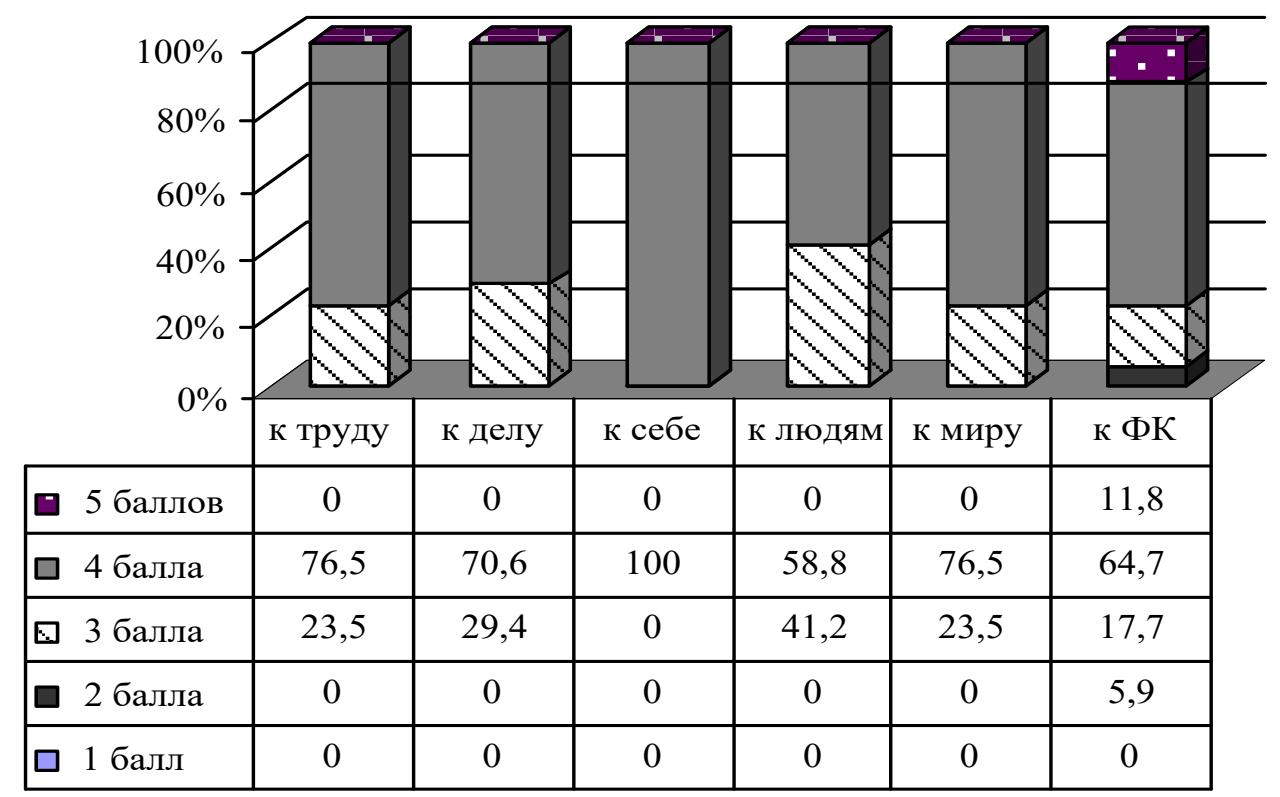

Рис. 6. Показатели сформированности отношений личности по разделам

проявили неровные и непостоянные отношения, не вызывающие серьезных нареканий окружающих и нуждающиеся в определенной коррекции (3 балла); у 64,7 \% опрошенных оказалась достаточно прочная и позитивная система отношений личности к физической культуре, но с некоторыми несущественными недостатками (4 балла) и 11,8 \% специалистов имеют разносторонность позитивных отношений личности (образец для других - 5 баллов). Эти данные свидетельствуют о повышенных требованиях к физической подготовленности лиц, занятых в своей профессии, и отсутствием в современном процессе ПФК направленности педагогических воздействий на личностные качества, свойства и черты характера.

Наряду с этим практически одинаковое количество баллов оказалось в сформированности отношений «ктруду» - трудолюбие, добросовестность, аккуратность, организованность и т.д. $(3,7)$ и «к делу» - самостоятельность, уверенность, наличие таланта, целеустремлленность и т.д. $(3,7)$. Наиболее низкую оценку получили отношения «к людям и обществу» - общительность, вежливость, порядочность, требовательность, откровенность и т.д. (3,6 балла), с самым высоким показателем разница составляет $10 \%$ и является статистически достоверной $(\mathrm{P}<0,05)$.

Интегральный показатель личностных свойств и качеств составил 3,8 балла, что на 5 \% меньше оценки 4 «хорошо» и свидетельствует о достаточно прочной и позитивной системе отношений личности, но с некоторыми несущественными недостатками. При этом $76 \%$ опрошенных в целом оценили себя на 4 балла и 24 \% на 3 балла.

Таким образом, результаты исследования позволили обосновать необходимость направленности ПФК на формирование профессиональных личностных свойств и качеств специалистов.

\section{Результаты исследования и их обсужление}

В настоящее время признано, что физическая культура является важным фактором повышения экономической эффективности современного производства и социального развития трудовых коллективов, поэтому 
исключительно важное значение имеет идейная и профессиональная направленность личности, социальная активность. В связи с этим инженер обязан не только сам заниматься физической культурой, но и умело использовать её средства и методы для решения этих задач.

Однако изучение физкультурной активности инженеров-мостостроителей показало, что только 14 \% из всех анкетированных регулярно занимаются какими-либо формами физической культуры самостоятельно в свободное от работы время (рис. 7).

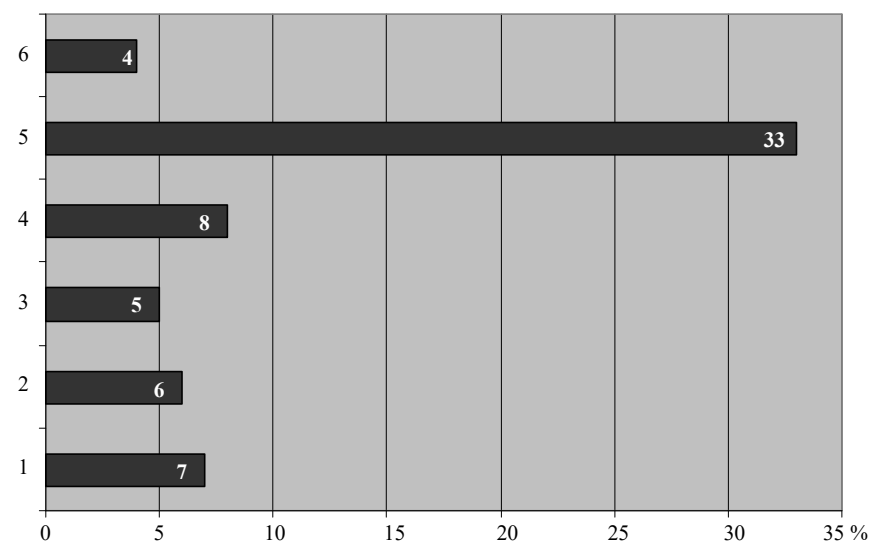

Рис. 7. Активные формы двигательной деятельности: 1 - утренняя гимнастика; 2 - занятия по ТВ; 3 - настольный теннис; 4 - рыбная ловля; 5 - отдых: за грибами, садовый участок, поездка за город; 6 - другие

Большинство опрошенных (33\%) в качестве активной формы двигательной деятельности используют выезды за город, за грибами, работа на садовом участке; 8 \% - рыбную ловлю; 7 \% - нерегулярно выполняют утреннюю гигиеническую гимнастику.

В качестве основной причины проявления недостаточного внимания к занятиям физической культуры и спорта основная часть опрошенных отметили усталость - $38 \%$; $33 \%$ - отсутствие желания и $5 \%$ - состояние здоровья.

Следует подчеркнуть, что большинство обследуемых (76 \%) осознают значение физической культуры, как фактора успешной производственной деятельности, 81 \% отмечают, что систематические занятия физической культурой способствуют снижению утомления во время работы. Из числа опрошенных 43 \% указали, что недостаточная физическая подготовленность мостостроителей обусловлена неудовлетворительной организацией физической культуры на производстве; 39 \% - несовершенством процесса физического воспитания в школе; $19 \%$ - невысоким уровнем постановки физического воспитания в вузе.

Негативным явлением в двигательной активности инженеров является недостаточное внедрение комплекса общепринятых форм организации физической культуры, слабая спортивная база, отсутствие общественных физкультурных кадров, недостаточно широкое использование различных средств и форм агитационно-пропагандистской работы по физической культуре.

Интерес представляют результаты социально-педагогического исследования по выявлению целостной структуры профессиональной физической культуры личности специалистов по строительству мостов и транспортных тоннелей, результаты которого позволяют обосновать стратегию педагогических воздействий на студентов в период их профессионального образования.

Одним из компонентов этой структуры, определяющим сформированность «личности профессионала», является аксиологический, который предполагает ориентированность личности на овладение совокупностью ценностей ПФК и связанных с социальной и профессиональной деятельностью.

Овладение ценностями ПФК предполагает осознание и освоение личностью своими физическими способностями, значений форм, средств и методов физкультурного самосовершенствования.

Критерием ценностной ориентированности личности следует считать осознание ею ПФК ценностью «для себя» и общества, непосредственное участие в самодеятельном физкультурном совершенствовании, ведение здорового образа жизни.

Изучение ценностных ориентаций личности (ЦОЛ) инженеров-строителей мостов и транспортных тоннелей осуществлялось с помощью модифицированной методики по оздоровительному и профессионально-прикладному направлениям.

В ходе социологического опроса приняли участие работники Дальмостостроя (84 чел.), имеющие высшее профессиональное образование и стаж работы по специальности не менее 5 лет.

Результаты опроса показали, что ценностные ориентации личности в сфере двигательной активности специалистов данного профиля сформированы на 60,7 \% от максимально возможного проявления. При этом отмечен низкий уровень сформированности информационно-познавательного компонента - 45,4 \% и относительно высокий оценочно-мотивационного компонента ценностных ориентаций - 68,8 \% (рис. 8).

Иначе говоря, работники изучаемой специальности осознают роль и значение ПФК в повседневной жизни и профессиональной деятельности, у них сформирована достаточно уверенная установка на физкультурное и 


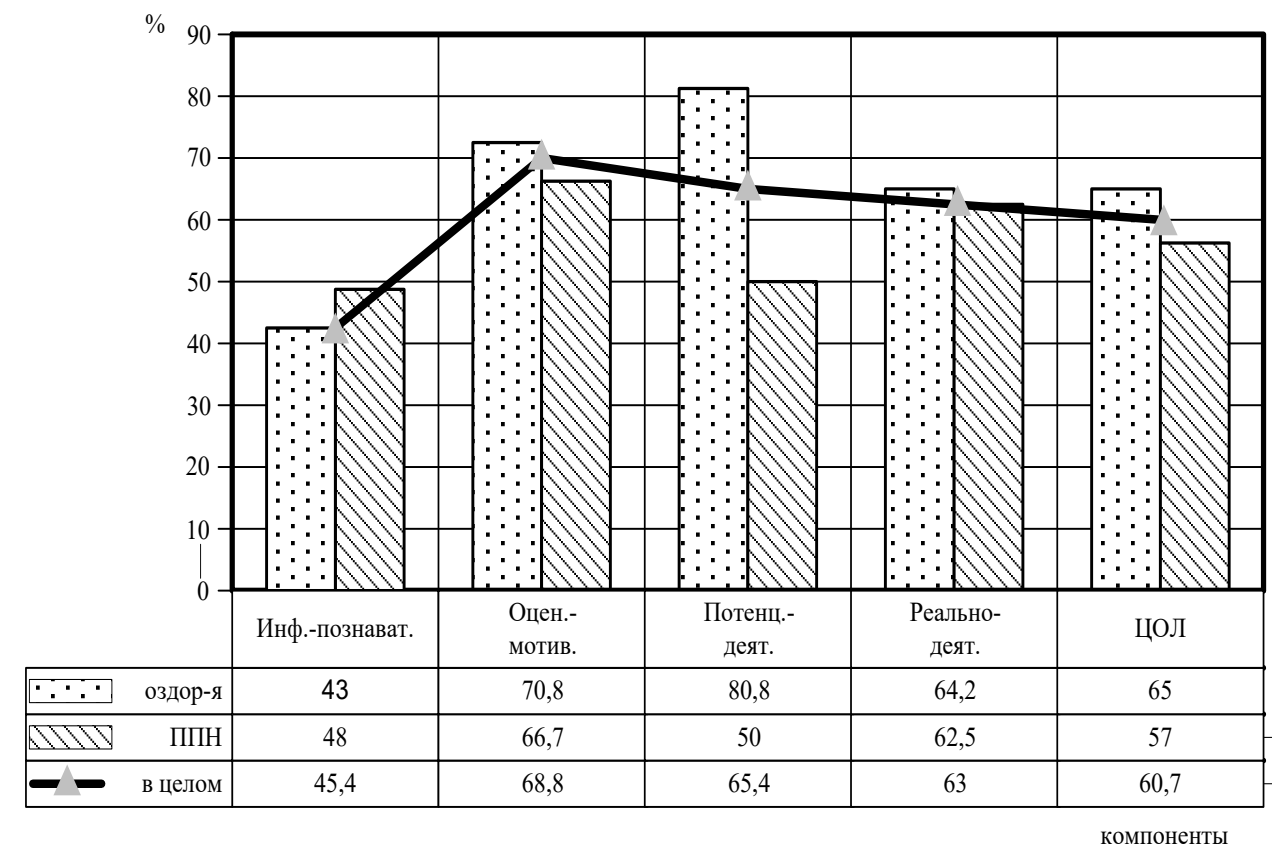

Рис. 8. Показатели сформированности двигательной активности личности в сфере ценностных ориентаций

профессиональное самосовершенствование. При этом отмечается недостаточная их осведомленность в вопросах теории и методики физического воспитания и ведения здорового образа жизни.

Полученные данные позволяют судить о необходимости целенаправленного формирования информационно-познавательного компонента будущих специалистов по строительству мостов и транспортных тоннелей в системе базового профессионального образования.

Наряду с этим анализ результатов исследования показал значительную разницу уровней потенциально-деятельностного компонента у оздоровительного (80,8 \%) и профессионально-прикладного направлений (50\%). Иными словами, большинство опрошенных отметили уверенное освоение двигательных умений и навыков, используемых в повседневной жизни с целью укрепления здоровья и физического совершенствования.

Однако значительная часть респондентов проявила явные затруднения в овладении средствами профессиональной физкультурной деятельности, что свидетельствует о недостаточном уровне профессиональноприкладной подготовки работников Дальмостостроя в период их профессионального становления на этапе обучения в вузе.

В ходе исследования были выявлены несовпадения между потенциальной и реальной деятельностью оздоровительного и прикладного направлений. В первом случае реальная деятельность отстает от потенциальной на 24,6 \%, а во втором (профессионально-прикладном) направлении, наоборот, реальная деятельность опережает потенциальную на 12,5 \%. В целом же, ценностные ориентации личности оздоровительной направленности сформированы на 65 \%, а профессионально-прикладной - на 57 \%. Оба эти показателя расположены в области «средних величин», что свидетельствует о существующих возможностях совершенствования данного качества личности.

Таким образом, полученные данные служат методологической основой определения направленности педагогических физкультурных воздействий на процесс формирования структуры профессиональной физической культуры личности студентов по специальности «мосты и транспортные тоннели».

\section{Выводы и практические рекомендашии}

Результаты исследования профессиональной деятельности мостолстроителей показал, что специфика труда на строительстве мостов обусловлена сложным комплексом работ, большая часть которых выполняется в условиях повышенной опасности: на значительной высоте, над водой и под водой, при высокой волне и др. Ведущими факторами, определяющими условия труда являются: неблагоприятные метеорологические условия, существенное загрязнение воздуха рабочей зоны, высокие уровни шума и вибрации, недостаточная освещенность.

Анализ наблюдений, бесед, опроса квалифицированных специалистов показал, что степень профессиональной подготовленности мостостроителей в наибольшей степени обусловлена показателями быстроты, общей и 
силовой выносливости, подвижностью в суставах рук, гибкости, равновесия, уровня развитии функции внимания, эмоциональной устойчивости, личностных качеств, составляющих структуру организаторских способностей (коллективизм, решительность, самообладание и выдержка, инициативность, способность объективно оценивать людей).

Результаты проведённого исследования подтвердили необходимость включения в систему профилактических мероприятий по обеспечению безопасности мостостроительных работ прикладную плавательную подготовку.

Социологические исследования работников Дальмостостроя выявили сформированность у них ценностных ориентаций на двигательную деятельность преимущественно оздоровительной направленности (80,8 \%), в меньшей степени (50 \%) профессионально-прикладной направленности.

Выяснилось, что специалисты по строительству мостов и транспортных тоннелей осознают роль и значение профессиональной физической культуры в повседневной жизни и профессиональной деятельности. Однако обнаружен ограниченный уровень их знаний в вопросах теории и методики физического воспитания, ведения здорового образа жизни.

Полученные материалы ставят задачу необходимости целенаправленного формирования ПФК личности специалиста на этапе обучения в вузе и служат предпосылкой для обоснования её содержания при освоении рабочих и инженерных профессий мостостроителя.

На основе профессиографического анализа условий труда специалистов по строительству мостов и транспортных тоннелей была разработана экспериментальная программа, обеспечивающая комплексное и целенаправленное воздействие на личность профессионала. Она составлена на основе ныне действующих программ физического воспитания и отражает основное содержание курса физической культуры студентов вуза.

Содержание программы разработано согласно современным требованиям производства и экспериментально обоснована в условиях ДВГУПС, учитывая специфику этапов профессионального обучения студентов мостостроительной специальности [3, 4].

Основными методологическими требованиями разработки ее содержания явились: профилирование традиционных видов физкультурной деятельности с целью достижения прикладной подготовленности к современным условиям профессиональной деятельности; модернизация обязательного процесса физической культуры в соответствии с характерными особенностями профессионального физкультурного образования, предусматривающего обучение прикладному плаванию и воспитанию профессионально важных личностных свойств и качеств; осуществление в ходе профессиональной физкультурной деятельности комплекса мер педагогических воздействий на личностную сферу учащихся: систему её отношений, аксиологический и потребностномотивационный аспекты ПФК личности.

Особенностью экспериментальной программы явилась целевая направленность специализированного процесса физического воспитания на формирование не только профессионально важных физических качеств инженеров-строителей, но и личностных, ориентированных на овладение ценностей ПФК.

Разработанная программа ориентирована преимущественно на студентов 2, 3 и 4 курсов обучения, так как физическое воспитание студентов на первом этапе организуется соответственно содержания Государственной программы и имеет направленность создания фундамента ПФК, интенсивного развития базовых физических и психических качеств, формирования широкого фонда прикладных навыков.

По мере обучения, от курса к курсу проявляется тенденция повышения уровня прикладной психофизической подготовки студентов, как по объёму учебных занятий, так и по их профессиональной выраженности.

Если с первого по второй курс содержание программного материала имеет направленность на развитие и совершенствование (на базе общей физической подготовки) профессионально важных качеств, необходимых для мостостроителей, то на 3-м и 4-м курсе программный материал направлен в основном на формирование способностей и качеств личности инженера мостостроительного производства, овладение ценностями в сфере ПФК.

Основное содержание программы разделено на два блока. Первый блок - обязательный (базовый), обеспечивающий формирование основ физической культуры личности. В него включены разделы, содержание которых является обязательным для изучения. К ним отнесены теоретический раздел: «Основы формирования здорового образа жизни и профессиональной физической культуры», и практический: «Лёгкая атлетика», «Гимнастика», «Спортивные игры».

Второй блок - разделы по выбору, которые составляют плавание с элементами аутогенной тренировки, прикладное плавание.

Материал раздела, предназначенный для формирования информационно-познавательного, оценоч- 
но-мотивационного и потенциально-деятельностного компонентов ценностных ориентаций личности (ЦОЛ) студентов в сфере двигательной активности изучается на каждом занятии, которые проводятся в лекционной и методической форме.

Формирование реально-деятельностного компонента ЦОЛ в сфере двигательной активности обеспечивается посредством изучения содержания практического раздела. Подбор материала этих разделов позволяет развивать профессиональные способности студентов в рамках специализированных и комплексных занятий.

Разделы плавание с элементами аутогенной тренировки и прикладное плавание, введены за счет частичного сокращения традиционных разделов программы. Объем часов по этим разделам стабилен, меняется лишь направленность его содержания, что обеспечивает последовательное освоение знаний о значении психорегулирующей тренировки и практических умений использования её приёмов в процессе производственных практик и повседневной жизнедеятельности.

Содержание каждого раздела программы включает теоретический, практический и контрольный подразделы: основы знаний, практические умения и навыки, формы и методы контроля.

Таким образом, характерной особенностью процесса моделирования ПФК студентов на этапе профессионального образования является его направленность на удовлетворение социальной и личностной потребности в сформированности профессионала, что предопределяет углублённую профилированность обязательного процесса физической культуры на основах физкультурного образования.

Основными методологическими требованиями программно-содержательного моделирования процесса ПФК студентов мостостроительных профессий являются:

- профилирование традиционных видов физкультурной деятельности с целью достижения общеприкладной подготовленности к современным условиям профессиональной деятельности;

- модернизация обязательного процесса физической культуры в соответствии с характерными особенностями профессионального физкультурного образования, предусматривающего обучение прикладному плаванию и воспитанию профессионально важных личностных свойств и качеств;
- осуществление в ходе профессиональной физкультурной деятельности комплекса мер педагогических воздействий на личностную сферу учащихся: систему её отношений, аксиологический и потребностно-мотивационный аспекты ПФК личности.

Сформированность определённых элементов ПФК личности достигается при соблюдении преимущественной направленности прикладной физкультурной деятельности:

- спортивные игры - на формирование комплекса психофизических и двигательных способностей (простая и сложная двигательная реакция, переключение и распределение внимания, точность и ловкость движений), а также коммуникабельность, экстравертированность межличностных отношений;

- гимнастика - на формирование физических и психофизиологических качеств (статическая и силовая выносливость), вестибулярная устойчивость, координация движений, гибкость, скоростносиловые качества, культура движения, пластичность, а также аккуратность, дисциплинированность, настойчивость;

- лёгкая атлетика - преимущественное воздействие на функциональные возможности и скоростносиловую подготовленность, настойчивость, терпеливость, систему отношений к труду и физкультурной деятельности;

- плавание с элементами психорегуляции - на общую и специальную выносливость, на психофизическую и психоэмоциональную сферы личности, способность к физкультурному самосовершенствованию, потребностно-мотивационный аспект личности, духовность, культурный кругозор;

- прикладное плавание - приобретение навыков прикладной плавательной подготовки; обеспечение личной безопасности на воде и оказание помощи пострадавшему в экстремальных условиях, формирование профессионально важных физических способностей (общая и специальная выносливость, устойчивость к гипоксии, координация и быстрота движений), а также потребностно-мотивационный аспект личности;

- теоретическая подготовка - на формирование ЦОЛ на физкультурную деятельность, потребностно-мотивационной сферы, приобретение комплекса умений и навыков 3ОЖ, овладение теорией и методикой физической культуры.

\section{ЛИТЕРАТУРА}

1. ГОСТ высшего профессионального образования по специальности 27.15 .01 - строительство железных дорог и транспортных тоннелей. Квалификация «специалист» [Текст]. - Введ. 2010-24-12, №2052. - М.: Изд-во стандартов, 2011. - 13 с. 
2. Садовский, В.А. Система, формирующая профессионально-прикладную физическую культуру специалистов железнодорожного транспорта: монография [Текст] /В.А. Садовский, Ю.П. Бобылев. - Хабаровск: изд-во ДВГУПС, 2011. - с.с. $27-32$.

3. Смоляр, С.Н. Физическая культура и спорт в программе учебных занятий студентов неспециализированных вузов: учебное пособие [Текст]. /С.Н. Смоляр, Л.В. Царева, В.В. Мулин - Хабаровск: Изд-во ДВГУПС, 2008. - с.с. 5 -14.

4. Царева, Л.В. Основные аспекты модульного построения учебного процесса по физическому воспитанию студентов в вузе: учебно-методическое пособие [Текст] /Л.В. Царева, С.Н. Смоляр, В.В. Мулин. - Хабаровск : Изд-во ДВГУПС, 2011. - с.с. 5 -11.

5. Царева, Л.В. Физическая культура и спорт в образовательной деятельности высших учебных заведений: учебное пособие [Текст] /Л.В. Царева, С.Н. Смоляр, В.В. Мулин. - Хабаровск : 2-е изд., доп., перераб. Изд-во ДВГУПС, 2013. - с.с. $117-120$.

6. Царева, Л.В. Учебная программа профилированного физического воспитания студентов по специальности «Мосты и транспортные тоннели» / Л.В. Царева. - Хабаровск: Изд-во ДВГУПС, 2001. с.с. 3 -25.

7. Царева, Л.В. Профессиографический анализ деятельности инженеров-строителей мостов и транспортных тоннелей. Современные проблемы физической культуры и спорта [Текст] / Л.В. Царева // Материалы IV научной конференции молодых ученых Дальнего Востока / Отв. редактор В.Н. Томилов. - Хабаровск: Изд-во ДВГАФК, 2000. - с.с.77-81.

8. ЦЦарева, Л.В. Эффективность реализации технологии обучения студентов основам профессиональной физической культуры: Профессиональное образование: преемственность, реализация и качество: Материалы научной методической конференции: под ред. Б.Е. Дынькина и А.Н. Гануса. [Текст] /Л.В. Царева, С.Н. Смоляр, В.В. Мулин. - Хабаровск: Изд-во ДВГУПС, 2012. Том 1. - с.с 203-209.

9. ЦЦарева, Л.В. Особенности программно-содержательного обеспечения профессиональной физической культуры студентов вузов железнодорожного транспорта //Физическая культура и спорт: Вестник Бурятского государственного университета [Текст] / Л.В. Царева, С.Н. Смоляр, В.В. Мулин. - Улан-Уде: изд-во БГУ,2014.- №13.- С.177-182.

10. Царева, Л.В. Профессионально-прикладная направленность плавательной подготовки студентов вызов железнодорожного транспорта : учебное пособие [Текст] / Л.В. Царева, О.Е. Закорко, С.Н. Смоляр, В.В. Мулин. - Хабаровск: Изд-во ДВГУПС, 2020.- 117 с. : ил.

11. Царева, Л.В. Оптимизация процесса профессионального образования студентов средствами прикладной физической культуры: монография [Текст] /Л.В. Царева, С.Н. Смоляр, В.В. Мулин. - Хабаровск: Изд-во ДВГУПС, 2019. - 24-30 с.

○ Царева Любовь Васильевна (Lyubov.tsareva.60@mail.ru), Смоляр Сергей Николаевич (smolyar@list.ru), Мулин Владимир Васильевич (Mulin58@yandex.ru). 